Available online at: http://proceeding.rsfpress.com/index.php/ic-smart/index

Proceeding on International Conference of Science Management Art Research Technology

(IC-SMART)

Volume 1 Number 1 (2020): 168-174

\title{
The Role of SMEs in The Economic Development of Indonesia: A Study of Competition Law and Policy in The Field of Retail Industry
}

\author{
Anna Maria Tri Anggraini \\ Faculty of Law, Trisakti University, Jakarta \\ E-mail address anna.mta@trisakti.ac.id;
}

\begin{abstract}
Indonesian Anti-Monopoly Law provides for the exemption of business actors which belong to the category of small scale businesses. This is the materialization of the law's objective, namely ensuring equal opportunities to do business for large-, medium-, and small-scale entrepreneurs. Small-scale business actors who play a role in Indonesia's trading system include, among others, business actors engaging in the retail industry. The retail industry started to emerge with the proliferation of modern retail businesses in urban areas based on the franchise concept. In fact, there have been certain large retail businesses that have been proven to violate the Anti-Monopoly Law, particularly the prohibition of abusing a dominant position. With their presence, modern retail businesses have gradually replaced traditional retail businesses, which generally include small-scale enterprises (SMEs). The above-mentioned government policy on protecting small industries has been based on juridical, political as well as economic considerations. From the juridical point of view, there is a law concerning the treatment of medium, small, and micro businesses (MSMEs).
\end{abstract}

Keywords: retail industry, small and medium enterprises

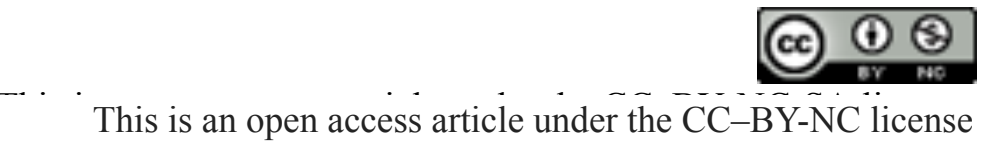

\section{INTRODUCTION}

Modern retail development replacing traditional markets at an increasing pace has become a phenomenon that needs to be observed as a form of change taking place in urban social lifestyle. Traditional markets require special attention from the central as well as from the regional government, considering that the conditions in economic activities undertaken by members of the middle-lower society are causing serious concern (Saswanda and Setiawan, 2014).

In principle, all of the above-mentioned regulations have the purpose of providing setting out the conditions of establishing and licensing for building modern retail businesses with due regard to several aspects such as urban spatial planning (regulation of zoning), the number of modern retail businesses related to the local population, partnership with MSMEs, as well as CSR (Corporate Social Responsibility). It is expected that by duly observing the above-described conditions, traditional markets and shops can be sustained in a mutually complementary manner. Indeed, this is 
Proceeding on International Conference of Science Management Art Research Technology (IC-SMART),

Vol. 1 (1), 168-174

The Role of SMEs in The Economic Development of Indonesia: A Study of Competition Law and Policy in The Field of Retail Industry

Anna Maria Tri Anggraini

in line with the objectives of Law Number 5 the Year 1999 concerning the Prohibition of Monopolistic Practices and Unfair Business Competition (Law No.5/1999).

The following issues can be stated: a) What is the role of small- and medium-scale industries in Indonesia's economic development, and why is there a need for the protection of MSMEs in the retail sector by the government? b) What forms of legal enforcement and policy have been implemented in the retail sector viewed from the Business Competition Law perspective?

\section{THE ROLE OF SMALL AND MEDIUM SCALE INDUSTRIES IN INDONESIA'S ECONOMIC DEVELOPMENT}

The changes are taking place in the international trade system towards liberalization, such ASEAN moving towards AFTA and subsequently towards becoming ASEAN Economic Community (AEC) in 2015, are bringing a lot of opportunities but also challenges and even threats to every entrepreneur from all scales of business. Opportunities include greater market opportunities compared to the world trade conditions segmented by protectionism implemented by many countries against imported products. On the other hand, challenges can be found in various aspects; for example, remaining competitive in the domestic market vis-à-vis foreign business actors entering Indonesia (Tambunan, 2013; Sitepu, 2014).

In the retail sector, for example, out of $20.98 \%$ of SMEs have stated that with the presence of modern retail businesses, sales turnover in the trade sector has decreased, with an average $25 \%$ decrease in the turnover of micro-businesses, $22.48 \%$ decrease in the turnover of small businesses, and $21.60 \%$ decrease in the turnover of medium businesses. A similar decrease in sales turnover has also occurred in the retail trade sector. The potential cause of such a decrease can be found in several factors, such as a wide range of market orientations and prices, as well as the quality of products/commodities which is not yet able to compete against products/commodities sold at modern retailers (Sitepu, 2014).

As the results of the above-described research projects indicate, the increasing number of modern retail businesses in the form of minimarkets, supermarkets, and hypermarkets in urban areas calls for an increased presence of traditional markets, and that is why the government issued Perpres 112/2007. The government's policy providing protection to traditional retailers, which are mostly SMEs, is in line with the objectives of Law Number 20 the Year 2008 concerning Micro, Small, and Medium Businesses. Law No. 5/1999 also provides for the protection to small businesses under Article 50 sub-article h) stating that "Exempt from the provisions of this law shall be business actors from the small scale business category. The philosophical basis is that the protection of small businesses is protecting small businesses against unfair business competition practices by larger business actors.

The government's endeavors for protecting small businesses through regulation can be considered as being relatively adequate; in fact, related to traditional retail business in the territory of the Capital City Jakarta (DKI Jakarta), the head of the region has issued Governor Instruction Year 2006, in principle putting on hold minimarket permits in the territory of DKI Jakarta (Governor Instruction Number 115, 2006). The Governor's consideration underlying the said Instruction has been the "increasing growth of minimarket activities reaching residential areas with the potential of creating unfair business competition" (Governor Instruction Number 115, 2006). In order to anticipate such unfair business competition, the Governor has limited minimarket business activities by putting on hold the processing for issuing permits for operating minimarkets (Governor Instruction Number 115, 2006).

Such abuse of permit for the establishment of modern retail business "wrapped" in the restaurant business is an indication of a weak control and law enforcement system in the modern retail sector, 
Proceeding on International Conference of Science Management Art Research Technology (IC-SMART),

Vol. 1 (1), 168-174

The Role of SMEs in The Economic Development of Indonesia: A Study of Competition Law and Policy in The

Field of Retail Industry

Anna Maria Tri Anggraini

leading to legal uncertainty in investment, which ultimately jeopardizes the existence of traditional retail businesses. The existing regulations, in the form of Law, Government Regulation, Presidential Regulation, Ministerial Regulation, and even Instruction of the Governor of DKI Jakarta, have proven to be incapable of stemming the surge of investment in the modern retail sector. Bearing in mind the above, there is a need for consistency and political will on the government's part, both at the central as well as the regional level, to implement the existing laws and regulations in an effort to provide protection to MSMEs, particularly in the traditional retail sector. In addition to the above, the government also needs to strengthen control in view of permits related to modern retail management, thus ensuring legal certainty and clear assurances to investors in the retail sector, particularly in facing the implementation of AEC in 2015.

\section{LAW AND POLICY IN THE MODERN RETAIL SECTOR VIEWED FROM THE PERSPECTIVE BUSINESS COMPETITION}

In the initial stage of the implementation of Law No. 5/1999 by the Indonesian business competition authority (KPPU), a case emerged related to the effects of the proliferation of minimarkets, which was considered as a causing factor of the elimination of traditional shops. The fast and significant growth of the number of modern retail businesses, and their penetration in residential areas and other strategic locations, had been partly caused by the lack of regulation in the management of the modern retail sector. There was a need for such regulation particularly in view of regulating zoning, the distance between modern retailers and traditional retailers, as well as the opening hours of modern retail shops, ensuring that the presence of modern retailers would not jeopardize the existence of traditional retailer businesses (Toya, 2014).

The case is related to the abuse of a dominant position and dominant market position by the largest hypermarket in Indonesia. The case started with reports from the community in principle, complaining that Carrefour had set trading terms that were harmful to suppliers as well as to Carrefour's competitors (KPPU, 2005). Carrefour had determined several types of trading terms to its suppliers, requiring annual increases such as for instance fix rebate, conditional rebate, common assortment fee, promotion fund, minus a margin, penalty (whereby late delivery was to be imposed for each outlet), anniversary discount (required as a regular discount), conditional fee, opening fee, common assortment fee, free goods and promotion budget, the listing fee (annual increase) and grand opening fee (including greetings/congratulatory fee) (KPPU, 2005). The listing fee is a fee for registering products per outlet, particularly at Carrefour. It was different from other retailers; however, this concept started to be implemented at various outlets.

One of the trading terms which was deemed to be harmful was the introduction of the minus margin system, basically prohibiting suppliers from selling their goods at Carrefour at a price higher than the price for goods of a similar type sold at other hypermarkets. If suppliers determined a price higher than the price of goods sold at Carrefour, such price difference would be multiplied by two and would be directly charged to suppliers to pay the discrepancy to Carrefour. KPPU had considered that Carrefour's conduct was a violation of Article 19 sub-article (b) and Article 25 paragraph (1) subparagraph a) of Law No. 5/1999 and imposed an administrative sanction of 1.5 billion Rupiah payable to the State Treasury.

A similar case occurred several years later by the same business actor. It started with the acquisition of Alfa Retailindo by PT Carrefour Indonesia, determining trading terms putting pressure on suppliers, resulting in monopolistic practices and unfair business competition (KPPU, 2009). The reason for PT Carrefour Indonesia acquiring PT Alfa Retailindo Tbk was to increase sales and the 
Proceeding on International Conference of Science Management Art Research Technology (IC-SMART),

Vol. 1 (1), 168-174

The Role of SMEs in The Economic Development of Indonesia: A Study of Competition Law and Policy in The Field of Retail Industry

Anna Maria Tri Anggraini

number of outlets as an additional format of modern retail in the form supermarkets following the trend of retail business moving towards multiformat business (KPPU, 2009).

In general, several trading terms had been applied by PT Carrefour Indonesia to its suppliers, including, among other things, listing fee, fixed rebate, minus a margin, term of payment, regular discount, common assortment cost, opening cost/ new store, and penalty. Suppliers complained that the listing fee and the minus margin were the most harming trading terms to them. The trading terms in the form of the listing fee required suppliers to pay a fee at the time of supplying new products at each Carrefour outlet, serving as a guarantee in the event that the goods concerned were not sold, being a single, non-refundable payment the amount of which was different for small and large suppliers, and in fact Carrefour's trading terms were considered to be incriminating by one of the supplier company witnesses (Lubis et al., 2009).

KPPU considered that PT Carrefour Indonesia's conduct was legally and conclusively proven to have violated Article 17 paragraph (1) concerning Monopolistic Practices and Article 25 paragraph (1) sub-paragraph a concerning the Abuse of Dominant Power under Law No. 5/1999. In the proving process, KPPU separated out the object of dispute in the upstream and the downstream market, respectively. The upstream market includes services related to the display of goods offered by Carrefour to its suppliers, while the downstream market includes the sale of goods by Carrefour to end-user consumers. In this case, the object was the upstream market, whereby upon acquiring $75 \%$ of PT Alfa Retailindo's shares, PT Carrefour determined extremely high trading terms to its suppliers, while they had no other choice due to the lack of an equal bargaining position.

As indicated in this case, the business competition agency's position is that dominant ownership can potentially lead to the abuse of market power, and it can hamper and/or harm other business actors, including competitors and even "partners". Law No. 5/1999 provides that a Dominant Position can occur if a business actor controls $50 \%$ or more of the market share for a certain type of goods and or services. However, it needs to be noted that the percentage does not necessarily have to be taken on the national scale, but rather in the relevant market.

Particularly in the retail market, trading terms can be potentially considered as a form of abuse of Dominant Position, namely in a situation where suppliers feel they are not given an opportunity to bargain before signing an agreement. The impression is that the supplier benefits from accepting the offer and that by rejecting the modern retailer's offer, such benefit would be lost. The offer is sometimes presented in the form of a threat, meaning that the supplier is left with no choice but to accept the terms put forward by the modern retailer concerned, making them a take it or leave it to offer. In contract law, it is referred to as 'unbalanced' conditions, whereby one of the parties has a stronger bargaining position than the other. At this point, Business Competition Law is applied to deal with the above-described phenomenon, whereby the said bargaining position is measured based on market power and various other variables.

There have been several instances of suppliers experiencing pressure or facing the threat of their orders or supplies being discontinued, thus being more harmful than accepting unfair trading terms. Several countries that apply Business Competition Law have studied this development and have, in fact issued Guidelines for dealing with such situations. In the Guidelines of the Japan Fair Trade Commission, this kind of situation is treated analogously with the abuse of Dominant Position.

An example of the abuse of bargaining position by modern retailers against suppliers is when a modern retailer requires its supplier to second its employees as promotional staff, but they end up being used not only for promoting their company's products but also for checking inventories and doing other work not related to the supplier's product. When asked why it agrees to do it, it becomes obvious that there is pressure and fear that unless the supplier complies, its supplies will be 
discontinued. In this case, the damage is incurred by providing complimentary employee services, and such damage is sustained in order to avoid greater damage, namely the discontinuation of its supplies.

Korea has applied similar regulations in the form of Guidelines "Criteria for Examining the Abuse of Market Dominant Position" dated May 16, 2002, from Notification No. 2002-6 Korean Fair Trade Commission. Just like Japan, Korea has stipulated several criteria referred to as the regular trading field, whereby competition may occur based on the transaction relation type, place, level, and partnership. The factors taken into account include the type of product (goods or services), the place, or market location affecting the cost of transport or travel time. Another factor taken into account is the level of transaction, namely transaction at the production, distributor, or retail level. The nature of the relationship in a transaction also takes into account the relationship pattern, whether it is between a number of entities or groups at the purchase or sales level.

Korea determines the criteria of business with Dominant Position based on market share and the barrier to entry factor. At the same time, the criteria for assessing the abuse of dominant market position is by considering unfair decisions made by business actors using their Dominant Position, maintenance cost as well as the cost structure occurring as a result of the unilateral decision. Such acts may also be considered as acts hampering other businesses in the execution of business activities through discriminatory measures, causing damage to their partners. Moreover, it can actually be in the form of coercion or pressure to refrain from doing business with other parties, particularly with competitors of the partner under such agreement. Such practices are considered to be a form of unfair trade practices, particularly if they involve unilateral decisions made by a party using its Dominant Position.

Several other countries have also issued regulation concerning the abuse of Dominant Position, which can potentially disrupt fair business competition, particularly for retailers, whereby profits are made by unfair behavior, while suppliers are harmed as they are under threat or in a state of concern. In the event of business agreements between suppliers and retailers, if such a situation occurs, the Contract Law principle as provided for in the Civil Code applicable in Indonesia is also violated, provided that the violation of the said principle is proven. The time has come for Indonesian regulators and law enforcement agencies to examine whether such injustices are indeed also taking place in the Indonesian retail market competition.

It is expected that KPPU's decision in the Carrefour case will contribute to the learning process concerning the abuse of Dominant Position from the aspect of bargaining position in the retail market. The abuse of Dominant Position against suppliers is bound to exert pressure on suppliers, with an impact on smaller competitor retailers, and with the potential of ultimately extinguishing traditional markets. As large retailers get the opportunity to grow because their competitors have gone out of business, their dominant power increases, making it possible for them to put further pressure on their suppliers, thus gaining increasing power to put even greater pressure on competitor retailers.

\section{CONCLUSION}

Based on the foregoing analysis concerning the need for the structuring of the modern retail sector and protection of the traditional retail sector, as well as for control and business competition law enforcement in view of Dominant Position, the following conclusions can be made:

1. SMEs play an enormous role in Indonesia, as evident from the rather significant number of small businesses and their ability to overcome the economic crises in 1998. Accordingly, the government needs to provide adequate protection, both in terms of regulations in the form of law and policy, as well as supervision in the structuring of the modern retail sector. It is expected that 
Proceeding on International Conference of Science Management Art Research Technology (IC-SMART),

Vol. 1 (1), 168-174

The Role of SMEs in The Economic Development of Indonesia: A Study of Competition Law and Policy in The

Field of Retail Industry

Anna Maria Tri Anggraini

by formulating law and central government policy accompanied by implementation at the regional government level, a balance will be created in business opportunities for micro, small, medium, and large business actors in accordance with the MSME Law and the Antimonopoly Law. There is a need for legal certainty and investment policy in anticipation of AEC in 2015, requiring all stakeholders to be prepared, both from the aspect of regulation and policy, behavior as well as supervision.

2. From the perspective of business competition, there have been endeavors towards achieving the objectives of Law No. 5/1999 through law enforcement and providing advice or recommendations to the government in the retail sector. Law enforcement measures have included investigation, examination, and issuing decisions in cases of the abuse of Dominant Position by a modern retailer against suppliers as well as a negative impact on competitors. Advice and recommendations have been given by providing inputs to the Central as well as the Regional Governments in order to conduct supervision related to permits and implement retail structuring in their respective regions, in order to ensure that a balance is created between small, medium, and large business actors.

\section{REFERENCES}

Commission Regulation Number 9 Year 2011 concerning Guidelines for Article 50 Sub-Article $\mathrm{h}$ of Law Number 5 Year 1999 concerning the Prohibition of Monopolistic Practices and Unfair Business Competition.

Dwi Susilo, "Dampak Operasi Pasar Modern Terhadap Pendapatan Pedagang Pasar Tradisional di Kota Pekalongan" (The Impact Of Modern Market Operation Towards Traditional Market Tradesman Income In Pekalongan City), http://journal.unikal.ac.id/m index.php/lppm/article/view/199. Accessed on March 15, 2014.

Government Regulation Number 17 Year 2013 concerning the Implementation of Law Number 20 Year 2008 concerning Micro, Small and Medium Businesses.

Government Regulation Number 57 Year 2010 concerning Consolidation, Merger and Acquisition of Shares in Companies Which May Potentially Cause Monopolistic Practices and Unfair Business Competition.

Hasiholan, Samuel. "Role of the SME Sector in Indonesia's Economy). Written on May 12, 2011. http://samuelhasiholan.wordpress.com/2011/05/12/peran-sektor-ukm-pada-ekonomi-indonesia, accessed on March 12, 2014.

I Nengah Toya, "Pasar Tradisional versus Pasar Modern" ("Traditional Market v. Modern Market"), http://diskominfo.karangasemkab.go.id/index.php/id/artikel/18-pasar-tradisional-versus-pasarmodern. Accessed on March 20, 2014.

KPPU's Decision Number 02/KPPU-L/2005 concerning the Violation of Trading Terms by Carrefour.

KPPU's Decision Number 09/KPPU-L/2009 concerning the Acquisition of Alfa by Carrefour.

Law Number 20 Year 2008 concerning Micro, Small and Medium Businesses.

Law Number 5 Year 1999 concerning the Prohibition of Monopolistic Practices and Unfair Business Competition.

Lubis, Andi Fahmi, et al. Hukum Persaingan Usaha Teks Dan Konteks (Business Competition Law Text and Context). Jakarta: KPPU, 2009.

Maria Hendriani, "Peran UMKM dalam Perekonomian Indonesia" (The Role of MSMEs in Indonesian Economy), written on December 20, 2012. http://mariahendriani.blogspot.com/ 2012/12/artikel-peran-umkm-dalam-perekonomian.html. Accessed on February 5, 2012.

Presidential Regulation Number 112 Year 2007 concerning the Structuring and Development of Traditional Markets, Shopping Centers and Modern Shops. 
The Role of SMEs in The Economic Development of Indonesia: A Study of Competition Law and Policy in The Field of Retail Industry

Anna Maria Tri Anggraini

Rasidin Karo-karo Sitepu, "Dampak Keberadaan Pasar Modern terhadap Kinerja Ekonomi Regional" ("The Impact of the Existence of Modern markets on the Performance of Regional Economy), QE Journal, Vol. 01, No. 01. http://qe-journal.unimed.ac.id/ edisi/epdf/1/ QEJ_Vol01 _No01_1_Rasidin.pdf. Accessed on March 10, 2014.

Tambunan, Tulus. "ASEAN Economic Community 2015: Opportunities and Challenges for Indonesian SMEs), Policy Paper No. 15 Maret 2013, ACTIVE Advocacy Team (Advancing Indonesia's Civil Society in Trade and Investment Climate), Kadin-Jakarta. http://active.kadinindonesia.or.id/front/policy_papers/IMG_20130618091656.pdf. 